\title{
NARRATIVA, MITO, CIÊNCIA E TECNOLOGIA: O ENSINO DE CIÊNCIAS NA ESCOLA E NO MUSEU
}

\author{
Maria Cristina Leal ${ }^{1}$ \\ Guaracira Gouvêa $^{2}$
}

Mostramos neste artigo as possibilidades e a necessidade de se trabalhar a alfabetização científica, integrando ensino formal, não-formal e divulgação científica. Entendemos que a perspectiva de alfabetização científica está diretamente vinculada ao ensino com base nas relações Ciência, Tecnologia e Sociedade - CTS. Após uma breve resenha do significado de alfabetização científica e CTS, ressaltamos a importância de se articular narrativa, mito, ciência

e tecnologia no ensino de ciências. Nos apoiamos em uma sondagem feita com 108 professores participantes de um curso, 18 participantes de um seminário e 12 observações de turmas em visita a um museu de ciências para retratar, de um lado, as possibilidades que os professores vislumbram de se trabalhar ciências via CTS e, de outro, as incoerências que emergem quando certos conteúdos escolares são explorados na visita de alunos a um museu de ciências.

\section{INTRODUÇÃO}

O espaço dedicado, atualmente na mídia, à divulgação científica, por meio de filmes e programas de TV, artigos de jornais e revistas, pode-nos dar a dimensão da importância que a ciência e a tecnologia têm no processo de transformação do mundo de hoje. Alguns desses veículos apresentam e discutem temas que permitem ao grande público conhecer certa dimensão dos problemas e das transformações a serem enfrentados em face do uso exacerbado da tecnologia. Entre eles, vale mencionar o bug do milênio, o qual faria com que o computador confundiria os dois últimos algarismos do ano 2000 com os do ano 1900, provocando problemas de diversos tipos e prejuízos calculados em US $\$ 600$ bilhões. Exemplos de problemas potencialmente gerados pelo bug do milênio são os satélites que sincronizam algumas usinas elétricas e o processo de transferências internacionais de fundos. Se o problema não fosse solucionado a tempo, as usinas deixariam de funcionar e a contagem de tempo, para transferência de fundos, se não fosse computada em segundos (como deve ser), seria em anos, o que acarretaria cobrança de juros que poderiam chegar à casa dos trilhões de dólares (Zuckerman, 1999: 3).

Um artigo de divulgação científica, publicado na revista Época, pode indicar como a mídia elabora idéias sobre os tipos de transformações que a ciência e a tecnologia (C\&T) apontam para o próximo milênio:

\footnotetext{
${ }^{1}$ Fac. Educação, UFF

${ }^{2}$ Depto Educação, Mast
} 
“(...) Conferimos as mais recentes tecnologias que as empresas estão desenvolvendo... Vimos doenças erradicadas, viagens a outros planetas, deficientes tendo uma vida melhor, plantas mais nutritivas e abundantes. Encontramos crianças estudando a centenas de quilômetros dos professores, computadores que vêem e falam, materiais ultra-eficientes, energias limpas e muito baratas" (França et al., 1999:37).

Além do espaço reservado para essa discussão na mídia, observa-se a crescente penetração desse debate nos livros didáticos e materiais paradidáticos. um fato a destacar é que, nos parâmetros curriculares nacionais, elaborados pelo mec (parâmetros curriculares nacionais, ciências naturais, 5 a $8^{\text {a }}$ séries, brasília, mec, 1998), tanto os do ensino fundamental como os do ensino médio, uma das diretrizes apontadas é a necessidade de se colocar, no currículo, o debate entre ciência, tecnologia e sociedade.

Tambem vale destacar "que a ciencia esta cada vez mais incorporada ao cotidiano das pessoas, mas poucos continuam tendo acesso a sua forma de organização e ao seu corpo de conhecimento". assim, "as ciencias naturais, enquanto patrimonio da humanidade, parte da cultura universal, tem justificado sua inclusão no curriculo escolar; por outro lado, não tem garantido que os alunos passem a identificar este conhecimento como um instrumental possivel de analise e interferencia no universo que os cerca" (pierson e hosoume, 1997: 87).

A dimensão pública do impacto da C\&T na sociedade nos levou a pensar na necessidade de uma pesquisa que se debruçasse sobre a relação CTS na educação. A partir daí, produzimos o projeto "Ciência, Tecnologia e Sociedade no contexto da alfabetização científica”, o qual foi desenvolvido de 1997 a 1999 com o apoio da Finep, do CNPq e da Faperj. Seu objetivo foi identificar e analisar as narrativas que, em contextos de ensino-aprendizagem formal e não-formal, discutissem a relação CTS, visando à formação do cidadão por meio da escola e do museu.

$\mathrm{Na}$ sua primeira etapa, a pesquisa esteve centrada, de um lado, no levantamento de informações sobre as visões dos professores (de ciências e de outras disciplinas) a respeito da possibilidade de se trabalhar a educação científica e tecnológica na escola através do estabelecimento da relação CTS. De outro lado, foi realizado um trabalho de observação de visitas de professores à exposição permanente do Museu de Astronomia e Ciências Afins (Mast/MCT), além de seminários para professores, com a finalidade de se dimensionar a relação entre educação formal e não-formal. O objeto da pesquisa - narrativas em CTS no ensino formal e não-formal, visando à alfabetização científica - mostrou a importância de discutirmos a relação entre narrativa, mito, ciência e tecnologia.

\section{NARRATIVA, MITO, CIÊNCIA E TECNOLOGIA}

\section{NARRATIVA}

Uma das formas de se apreenderem processos interativos a respeito de resultados de aprendizagens, que visem à ampliação do capital científico e tecnológico dos aprendizes. Consiste no levantamento de narrativas individuais e coletivas que expressem concepções de 
ciências e de seu ensino. Adotamos, para isso, o ponto de vista de Levine (1995), que defende, como meio válido de investigação, o estudo da narrativa coletiva de determinados grupos sociais:

“(...) O exame de histórias disciplinares produzidas pelos praticantes dessas disciplinas revela uma variedade de formas de narrativas. Em alguns casos, elas enfatizam o valor do trabalho científico em seu campo, como quando louvam as realizações de grandes cientistas ou glorificam a ciência como atividade humana distintamente progressista. Em outros casos, valorizam certas direções no trabalho científico, como quando reforçam uma determinada abordagem científica ou anunciam uma transformação conceitual no campo. Outras ainda servem para demarcar as fronteiras de um domínio intelectual, como quando celebram o surgimento de uma nova disciplina ou descrevem conexões com sistemas filosóficos antecedentes" (Levine, 1995: 22).

A reflexão de Levine sobre as narrativas nos inspirou em dois sentidos. O primeiro foi buscar saber, mesmo que por meio de uma sondagem exploratória (uso de questionário), como os professores (sujeitos partícipes de histórias disciplinares) se posicionavam diante de um momento de transição entre uma perspectiva de ensino tradicional de ciências e a abordagem de ensino via CTS. O segundo indicou a necessidade de se reconstituir um pouco da origem do ensino de ciências na perspectiva de CTS.

O valor da narrativa, nas pesquisas em ensino de ciências tende a crescer a partir de argumentos como os de Bruner (1996), para quem a ela constitui instrumento importante de compreensão do significado humano de aquisição de cultura. Para Bruner, a narrativa é um modo de pensamento que funciona por imagens, o qual não segue uma lógica linear, mas que é analógico e pode complementar o pensamento paradigmático (lógico-matemático ou científico). O pensamento narrativo consiste na prática de se contarem histórias a cada um para construir significados, dar sentido às nossas experiências. Uma diferença marcante entre os modos de pensamento narrativo e paradigmático é que, no primeiro, a capacidade abstrata surge do interesse particular, daquilo que é inesperado, irregular, enquanto que, no segundo, privilegia-se o abstrato isto é, os aspectos conceituais mais universais e gerais.

\section{O MITO}

O mito é tomado aqui em duas acepções básicas. Na primeira, identificamos o mito como afirmação e nos reportamos às narrativas tradicionais que, por tempo bastante longo, foram transmitidas de geração a geração para dar explicações acerca da origem do homem, do mundo, da vida. Essas narrativas diversificadas e transpassadas pelas vozes das culturas, das religiões, do imaginário, das relações de poder, do gênero etc. apresentam em comum o fato de manipularem a emoção, a crença, os dogmas. Na segunda acepção de mito, encontramos a sua negação, despolitização e esvaziamento. Tal acepção é formulada por Barthes (1993), quando estuda as maneiras como a sociedade burguesa cria seus mitos a partir de características como despolitização, esvaziamento de contextos, simplificação, ingenuidade e harmonia. 
Como exemplo de mito na primeira acepção, trazemos à cena a narrativa tradicional chinesa: Yi e os dez sóis. Esta relata a existência de dez sóis que, de modo revezado, ordenado, forneciam calor e luz à Terra até que, um dia, resolvem trabalhar juntos e começam a destruir a Terra (desordem). Somente com a intervenção do imperador da China e de um hábil arqueiro, a ordem se restabelece pela eliminação de nove sóis e a manutenção de apenas um. A narrativa traz a marca da cultura e do poder para dar conta de fenômenos naturais que se movimentam de forma ordenada/desordenada.

Para ilustrar a segunda acepção, recorremos a um trecho da análise de Barthes (1993) sobre o cérebro de Einstein:

“... claramente o funcionamento do processo, Einstein fotografado ao lado de uma lousa coberta de signos matemáticos de uma complexidade visível, quer dizer, como se trabalha a imagem de Einstein sempre se referindo, tentando fazer e dar o significado da sua genialidade; Einstein desenhando, isto é, tendo entrado portanto na lenda, uma vez mais de giz na mão, acabando de escrever sobre uma lousa limpa, como se preparasse a fórmula máxima do mundo. A mitologia respeita assim a natureza das tarefas, a investigação propriamente dita mobiliza engrenagens mecânicas, tendo como sede um órgão material monstruoso, apenas por sua complicação cibernética, a descoberta pelo contrário da essência mágica simples como um corpo primordial."( Barthes, 1993: 61)

Vemos, assim, a construção da representação do mito da genialidade por meio da capacidade máxima do homem de criar fórmulas capazes de decifrar os grandes segredos da natureza.

O mito encontra-se presente no discurso científico, alimentando seus encantos e desencantos, as suas contradições. A vontade de se superar o mito, na sua positividade, faz-se presente na ciência quando esta recorre às perspectivas criacionistas (Big-Bang, Teoria do Caos etc.) para explicar racionalmente as nossas origens, evolução, relações. O mito também se apresenta na ciência quando esta passa a priorizar o poder e a alimentar a crença em sua onipotência. Para Chrétien (1994), a hegemonia da ciência, nas sociedades modernas, coloca-a na condição de assumir as funções cujos titulares ela expulsou, isto é, os mitos.

Não tivemos aqui a intenção de esgotar, mas, sim, de introduzir uma discussão que entendemos necessária para os estudiosos da ciência e para aqueles engajados na perspectiva de educação em CTS. Consideramos necessário mencioná-la, pois ela orientou a primeira fase de realização da pesquisa.

No caso da pesquisa, os modos de pensamento narrativo e paradigmático ganham sentido quando analisados no contexto da alfabetização científica e numa perspectiva de ensino em CTS.

\section{CIÊNCIA, TECNOLOGIA E SOCIEDADE NO ENSINO DE CIÊNCIAS}

O conceito de alfabetização científica pressupõe, em linhas gerais, uma discussão que envolve a comunidade científica, a educacional e os profissionais de comunicação sobre o que o cidadão comum sabe e deveria saber a respeito da relação CTS. Como o que o cidadão 
comum sabe, ou deveria saber, a respeito dessa relação abrange, necessariamente, elementos ligados à sua formação e às informações disponíveis, essa discussão está situada no ensino de ciências praticado nas escolas e nos museus, na mídia e na Internet. Essas instâncias, dependendo de sua maior ou menor presença na sociedade, são as principais responsáveis pela formação da opinião pública a respeito de C\&T.

Ao definir o que é alfabetização científica, Shen (1975, apud Cazelli, 1992) estabelece três dimensões capazes de identificar o conceito a partir de variações em termos de objetivos, conteúdos, formas e público. A primeira é a dimensão prática, que habilita os indivíduos a resolverem problemas que exigem conhecimentos básicos; a segunda é a cívica, isto é, referese à consciência sobre os problemas e usos da C\&T; a terceira é a cultural, que consiste na obtenção de conhecimentos de C\&T aprimorados. Para Miller (1987), a alfabetização científica compreende a capacidade de o público entender os processos de investigação científica, as normas e os métodos da ciência, os temas científicos básicos e a consciência do impacto da C\&T sobre a sociedade. Finalmente, para Arons (1983, apud Cazelli, 1992), o indivíduo científica e tecnologicamente alfabetizado é aquele capaz de (1) compreender a distinção entre observação e inferência, isto é, de realizar exames minuciosos de dedução e raciocínio, distinguir entre papel da descoberta acidental e estratégia deliberada de formulação de hipóteses e de entender, através de exemplos específicos, que os conceitos e as teorias científicas são mutáveis e provisórios e precisam, portanto, de permanente aperfeiçoamento; (2) reconhecer que os conceitos científicos são elaborados pela inteligência e imaginação humanas e que, para serem entendidos e aplicados, devem ser operacionalizados; (3) desenvolver conhecimentos básicos que possibilitem uma leitura inteligente e uma aprendizagem permanente, sem necessidade de recursos exclusivos do ensino formal; finalmente, (4) ser capaz de entender que a relação CTS envolve aspectos morais, éticos e sociais. Para Barros (1990: 86), "a sociedade moderna exige de todos os seus cidadãos uma compreensão básica da ciência e da tecnologia, devido ao papel que estas possuem para a vida pessoal dos indivíduos. Trata-se, pois, de pensar na alfabetização científica de todos os integrantes da sociedade..." Morin (1996) e Angotti (1991) consideram que a sociedade deva ser alfabetizada científica e tecnologicamente para que tenha algum controle sobre o sistema ciência $e$ tecnologia.

A raiz deste debate é, no entanto, mais ampla e se localiza na relação CTS, questão complexa que vem sendo discutida por filósofos, sociólogos e educadores. Os primeiros têm-se dedicado, principalmente, a qualificar os conceitos de C\&T, a estabelecer relações de dependência entre eles, a afirmar ou negar a possibilidade de a tecnologia ter autonomia em relação à ciência, a identificar e diferenciar os problemas metodológicos das pesquisas científicas e tecnológicas; a refletir sobre a capacidade da tecnologia de garantir o progresso ou de levar a humanidade à autodestruição. Já os sociólogos, a despeito de tratarem de algumas dessas questões, estão empenhados em discutir a fundo duas teses que, no campo da ciência social, se confrontam e antecedem qualquer outro tipo de debate sobre CTS. Trata-se do problema determinismo da sociedade sobre a tecnologia versus autonomia da tecnologia sobre a ordem social. Finalmente, os educadores centram-se na problemática de discutir se o ensino em CTS representa uma crítica ou um aperfeiçoamento às formas tradicionais de ensino de 
ciências, se a abordagem científica por meio de CTS deve ser ou não institucionalizada na escola, com que objetivos e como deve ser tratada nos currículos e programas escolares.

Da Filosofia da Ciência e da Tecnologia, cabe destacar que a relação CTS tem seus primórdios na sociedade moderna, na qual se situam os conhecimentos produzidos por Galileu e Newton. Fundamentados na Física e na Matemática, a observação e os dados ganham, por meio desses conhecimentos científicos, representações possíveis de serem mensuradas e logicamente aplicadas. Abre-se, a partir daí, a possibilidade de a tecnologia se firmar e se desenvolver, uma vez que ela consiste na "aplicação de vários conhecimentos científicos reunidos com vistas à realização de uma finalidade prática”. (Rodrigues, 1997: 12)

Na Sociologia, a discussão sobre a capacidade de a ciência e a tecnologia moldarem a sociedade ou de serem moldadas por ela não é recente e remonta aos primórdios da Revolução Industrial. Entre os deterministas tecnológicos atuais, encontramos Mcluhan (1967) e Robeens e Webster (1989). Segundo esses últimos, o uso do computador deverá transformar o mundo social em todos os níveis.

Os críticos do determinismo tecnológico afirmam que os aspectos sociais e os temas políticos contam mais do que a tecnologia em si, pois importa saber principalmente "quem usa, quem controla, para que usa, como se amolda na estrutura de poder, como é expandida e distribuída a tecnologia". (Finnegan, 1988: 176)

Seja ou não a tecnologia o determinante da ordem social o fato concreto é que o debate sobre a relação entre elas se intensificou e ganhou contornos muito nítidos nos meios intelectuais e educacionais. No contexto do ensino, a complexidade dessa relação cresce em um mundo globalizado. Graças ao acentuado e acelerado progresso tecnológico, há uma exigência cada vez maior de cidadãos capazes de competências cognitivas específicas para administrar o cotidiano. Na escola, essas competências precisam ser oferecidas às novas gerações, o que exige reformulação na cultura escolar. Vale salientar que a idéia de cultura escolar pressupõe a transmissão de saberes, competências, formas de expressão, mitos e símbolos socialmente reconhecidos por meio de transposições didáticas, isto é, transmissão mediada da ciência do sábio, da obra do artista, do pensamento do filósofo nas matérias e disciplinas, nos exercícios e textos escolares etc. A transposição didática, por sua vez, impõe o aparecimento de configurações cognitivas específicas - saberes e modos de pensar tipicamente escolares (Forquin, 1993). Assim, coloca-se a questão de como inserir nas práticas educativas escolares o debate CTS.

A relação educação e tecnologia é tema polêmico em voga entre educadores. Há correntes mais ajustadas aos interesses empresariais que entendem a escola como espaço de formação geral mínima para produção de trabalhadores flexíveis e propensos a serem rapidamente treinados e reciclados no próprio local de trabalho. As correntes contrárias a essa visão não consideram que a escola deva fornecer o mínimo, mas algo próximo ao mínimo múltiplo comum, ou seja, garantir

"(...) uma formação polivalente que capacite para desempenhar uma família de empregos qualificados e, sobretudo, para compreender as bases gerais, técnico-científicas e socioeconômicas de produção em seu conjunto, que reúna a aquisição de habilidades $e$ destrezas genéricas e específicas com o desenvolvimento de capacidades intelectuais $e$ estéticas; que unifique, em definitivo, formação teórica e prática”. (Enguita, 1988: 51) 
No Brasil, a partir da década de 90, emergem elaborações sobre o conceito de alfabetização científica e tecnológica, apreendida por nós como o que o público deve saber sobre ciência, tecnologia e sociedade (CTS), com base em conhecimentos adquiridos em contextos diversos (escola, museus, revistas etc.), atitude pública sobre ciência e tecnologia, informações obtidas em meios de divulgação científica e tecnológica. As articulações entre ciência e tecnologia e sociedade por meio de práticas educativas, na escola e fora dela, definirão tipos de alfabetização científica e tecnológica; assim, nas escolas, o ensino de ciências e a divulgação científica nos meios de comunicação são elementos articuladores dessa relação.

Esse enfoque do ensino de ciências há muito é discutido em vários países. Um dos estudiosos da questão, o pesquisador inglês Ziman é crítico do ensino tradicional fragmentado em disciplinas, com o propósito de transmitir uma "representação esquemática idônea de um grande repertório de observações e dados experimentais" (Ziman, 1985: 39), o qual, em geral, consegue apenas parodiar o processo real de investigação científica. Para ele o ensino de CTS deveria substituir o ensino tradicional, pois permitiria, de forma interdisciplinar (ciência, tecnologia, psicologia, história, filosofia, sociologia), romper a impressão unilateral do ensino tradicional. No seu entendimento, a principal meta do ensino de CTS deve ser a de "opor-se ao cientificismo e tecnocracia e rechaçar qualquer fórmula estreita que pretenda conhecer todas as perguntas e todos os problemas de nosso tempo". (Ziman, 1985: 152)

Outra estudiosa inglesa do movimento de CTS no ensino é Solomon (1993). Para ela, o ensino de CTS deve visar, sobretudo, ao desenvolvimento de atitudes para se enfocar e solucionar, de modo significativo, os problemas da aplicação da ciência na sociedade, além de se ensinar a compreender o modo como a ciência atua no contexto social. Solomon aponta, como características específicas de CTS na educação, a compreensão das ameaças ambientais para a qualidade de vida de todo o globo, a compreensão de que a ciência tem uma natureza falível, a discussão de opiniões e valores sociais para produção de ações democráticas e a dimensão multicultural de visão de CTS.

O movimento de CTS no ensino não ficou restrito ao contexto inglês. Revela-se, na verdade, como a tendência dominante nos anos 90 e tem-se expandido para diversos países, dentro dos quais destacamos os projetos: PLON (holandês), SISCON e SATIS (britânicos), APQUA (Califórnia - EUA), e o Projeto 2001 (EUA), do qual originou-se o livro "Ciência para todos" (Rutherford e Ahlgren, 1995). No Brasil, dentre outros, destacam-se as experiências do Grupo de Reformulação do Ensino de Física - GREF-USP (1991) e Física - Coleção Magistério (1991).

Nos EUA, por exemplo, uma das preocupações do movimento de CTS consiste em produzir "uma compreensão de conceitos científicos-chave que unifiquem as ciências com outras disciplinas e que dêem conta das interações entre CTS" (Rye, 1998: 3).Outra intenção da educação em CTS "é de fazer com que os estudantes fiquem mais motivados para aprender ciência e conduzir melhor os experimentos científicos" (Scharmann,1998: 3). Na Austrália o ensino de CTS é entendido de modo interdisciplinar (perspectiva de Ziman) e se preocupa em discutir as origens, a natureza e o impacto social da C\&T (Hallingen, 1998: 2). Para Menezes (1988), Zanetic (1989) e Angotti (1991), os conhecimentos científicos, abordados nas escolas 
brasileiras, constituem-se em fragmentos de uma ciência, descolados de qualquer outra área de conhecimento.

Ao se inserir a discussão CTS no ensino de ciências, considera-se que "o aluno é um ser social, a apropriação do conhecimento científico como elemento importante na capacitação do sujeito para o pleno exercício de sua cidadania. O olhar da ciência enquanto parte importante da cultura, que, por direito, pertence ao aluno e por esta razão deve ser a ele devolvida, decodificada, leva a uma outra organização do conhecimento" (Pierson e Hosoume, 1997: 89). Realizar esse debate "não significa defender uma ciência do como funciona. $A$ sociedade atual não é apenas tecnológica pelos aparatos e instrumentos que incorporou ao nosso dia-a-dia, mas, principalmente, pela forma através da qual passamos a ver e interpretar as coisas à nossa volta, as explicações que procuramos dar aos eventos, às profissões de fé que fazemos a cada momento" (Pierson e Hosoume, 1997: 88). Para Auler (1997), uma forma de se introduzirem temáticas na perspectiva CTS no currículo convencional são as intervenções curriculares e o trabalho sistemático de acompanhamento os quais podem fazer surgir conflitos. "Conflitos, estes, que se estabelecem entre a satisfação de um trabalho diferenciado, reconhecido por professores e alunos, e as práticas rotineiras. Destes conflitos emergem espaços, aberturas, para alterações curriculares mais abrangentes". (Auler, 1997: 191)

No âmbito do ensino, é preciso mencionar as críticas dirigidas à introdução da CTS nos currículos escolares as quais atentam para o perigo de se utilizar o conhecimento sociológico como mais um mecanismo de controle e de reforço à valorização da C\&T:

“(...) Uma análise do discurso da educação CTS pode conduzir à previsão de profundas alterações na educação científica. É, sem dúvida, uma mudança, mas não é profunda. $A$ educação CTS torna claras e sem ambigüidades as relações de poder entre categorias (discursos, agentes, agências), legitimando a função reprodutora da escola. O elevado estatuto e poder actualmente atribuídos à ciência e à tecnologia na sociedade são agora subtilmente introduzidos na escola. E a vez dada às ciências sociais, nomeadamente à sociologia, dentro e fora da escola, representa apenas, como foi dito, uma modalidade de controle que permite dar mais força à força da ciência e da tecnologia ."(Moraes, 1994: 97)

O uso da inovação CTS para fins de reforço e de legitimação do status quo, sem dúvida, é um dos problemas a serem considerados quando se pensa num ensino em CTS.

À medida que caminhamos em direção a uma perspectiva de ensino e de alfabetização científica e tecnológica com base na relação CTS, procede também a busca de integração entre modos de pensamento narrativo e paradigmático que levem em consideração, inclusive, 0 papel de pensamento mítico, gênese dos modos de pensamento anteriormente mencionados.

Entendemos que a investigação de práticas educativas, por meio das narrativas, nos ensinos formal e não-formal, pode apontar as possibilidades de articulação entre mito, ciência, tecnologia e sociedade na medida em que o mito, além de ser considerado o ponto de partida dos pensamentos narrativo e paradigmático, encontra-se presente no cotidiano. Além disso, o discurso científico é considerado por alguns estudiosos como um dos mitos da sociedade 
contemporânea. Vale lembrar ainda que a tecnologia pode, em algumas circunstâncias, reforçar a ciência como mito e ser referência importante de organização da vida social.

\section{A INVESTIGAÇÃO}

\section{METODOLOGIA}

Nossa investigação teve caráter exploratório e focalizou fragmentos de narrativas de professores, profissionais do MAST - Museu de Astronomia e Ciências Afins e alunos que participam de processos de alfabetização científica e tecnológica. Nas escolas e nos cursos de atualização e aperfeiçoamento de professores, tivemos a oportunidade de aplicar um questionário (anexo 1) para saber como eles lidam hoje com a relação CTS (mesmo que ainda inseridos em um contexto de ensino tradicional). Foram distribuídos cerca de 500 questionários; em geral, os professores os levavam para casa, com a promessa de devolvê-los preenchidos. Retornaram 108 (21\%) deles, os quais foram digitados e tabulados no programa Sphinx. Esse programa, além de produzir tabelas e gráficos, também quantifica termos, conceitos e expressões através da análise de conteúdo. Além do questionário, trabalhamos especificamente com os professores, em dois seminários, propondo-lhes atividades que visaram a levantar as representações desses agentes sobre o tempo.

A temática do tempo foi explorada em seminários de atualização realizados em duas situações: num projeto de extensão da Universidade Federal Fluminense e no Museu de Astronomia e Ciências Afins, ambos no Estado do Rio de Janeiro. O museu foi também o local escolhido para acompanharmos visitas de 11 turmas à sua exposição permanente. Durante as visitas, valemo-nos do método da observação direta para levantar dados sobre 0 comportamento dos visitantes (anexo 2). Os dados e as análises a seguir dão uma idéia do que foi investigado.

\section{DADOS, RESULTADOS E ANÁLISES}

\section{CTS NO ENSINO FORMAL}

$\mathrm{Na}$ pesquisa sobre alfabetização científica e tecnológica que estamos desenvolvendo elaboramos e aplicamos, na sua fase inicial, um questionário para saber em que medida os professores de ciências estão atentos à discussão da relação CTS. As tabelas 2 e 3 (anexo 3) traçam um perfil dos professores pesquisados em termos de disciplina lecionada, série de atuação, tipo de escola e tempo de magistério. Por elas, observamos que o número maior de respondentes é da área de ciência, ecologia e biologia (40\%), seguidos de professores que lecionam no ensino de $1^{\underline{a}}$ a $4^{a}$ séries- núcleo comum (18\%). Os professores atuam, na sua maioria, na rede pública (72\%). Quanto ao tempo de magistério, constatamos que, em primeiro lugar, aparecem os que lecionam pelo menos há 6 anos (22\%), seguidos dos que têm entre 11 e 17 anos de magistério (11\%). A despeito da variação de tempo de magistério, em geral, os professores tendem a seguir um padrão tradicional de ensino de ciências determinado pelas orientações contidas nos currículos oficiais e nos livros didáticos. 
Quando perguntamos sobre a relação dos conteúdos hoje ensinados com a CTS, obtivemos os resultados que são apresentados na tabela e nos quadros abaixo:

\section{Tabela 1 - Relação entre Conteúdos Escolares e CTS:}

\begin{tabular}{|lcc|}
\hline Respostas & $\begin{array}{c}1^{a} \text { a } 4^{a} \text { séries } \\
N=25\end{array}$ & $\begin{array}{c}5^{a} \text { a } 8^{a} \\
N=26\end{array}$ \\
\hline Todos & 11 & 15 \\
Quase todos/ maioria & 04 & 01 \\
Ciências Biológicas & 02 & 00 \\
Questão ambiental & 02 & 07 \\
Não responde & 06 & 03 \\
\hline
\end{tabular}

\section{Quadro 1 - Detalhamento dos conteúdos escolares, conceitos científicos e CTS de 1a a 4a séries:}

\begin{tabular}{ll}
\hline Relação Conteúdos Escolares e CTS & $\begin{array}{l}\text { Conceitos Científicos } \\
\text { Identificados }\end{array}$ \\
\hline $\begin{array}{l}\text { Esquema corporal, tempo e relógio } \\
\text { Trabalho, força, corpo e necessidades alimentares } \\
\text { Recursos naturais, seres vivos, noções de higiene, } \\
\text { planeta }\end{array}$ & $\begin{array}{l}\text { Tempo, espaço } \\
\text { Transformação, conservação } \\
\text { Desmatamento, alimentação, reciclagem do lixo }\end{array}$ \\
$\begin{array}{l}\text { Saúde, higiene, meio ambiente } \\
\text { Sexo, drogas, violência, meio ambiente }\end{array}$ & $\begin{array}{l}\text { Transformação, conservação } \\
\text { Saúde, conservação }\end{array}$ \\
\hline
\end{tabular}

\section{Quadro 2 - Detalhamento dos conteúdos escolares, conceitos científicos e CTS de $5^{\text {a }}$ a 8 séries:}

\section{Relação Conteúdos Escolares e CTS}

Conceitos Científicos Identificados

Radiações, poluição ambiental, química dos

Transformação, conservação,

alimentos, fome, desperdício e reaproveitamento preservação, saúde, acumulação

de alimentos

Usina nuclear, informatização

Transformação, comunicação

Formação do Universo, sistema solar, planetas Tempo, espaço

Corpo humano, Aids, câncer, aborto, controle de Saúde, prevenção, demografia

natalidade

Energia atômica, energia elétrica, utilidade das

máquinas no cotidiano

Transformação, conservação, cotidiano

Sistema solar, tratamento e qualidade da água, Tempo, espaço, transformação, 


\begin{tabular}{|ll|} 
tecnologia ambiental, ciclos e importância das & meio ambiente, ciclos \\
florestas & \\
Ecologia e seres vivos & Meio ambiente, ciclos \\
Física aplicada, energia & Conservação, cotidiano \\
Ecologia, corpo humano, genética & Ciclos, transformação, informação \\
Doenças epidemiológicas & Saúde, prevenção \\
Matéria, energia, poluição do ar, água, origem da & Transformação, conservação, \\
vida, nutrição e saúde & ciclos, evolução, saúde \\
Tempo, espaço, terra & Tempo, espaço, meio ambiente \\
Biodiversidade & Evolução, biodiversidade \\
Drogas, invenções e sexualidade & Prevenção, conservação, cotidiano \\
Genética, eletricidade, eletromagnetismo & Informação, transformação, \\
& conservação \\
Clonagem, drogas, sexualidade & Informação, prevenção \\
\hline
\end{tabular}

A tabela 1 mostra como os professores de $1^{\underline{a}}$ a $8^{\underline{a}}$ séries respondem sobre os conteúdos com os quais trabalham e as possibilidades de explorar neles a relação CTS. Para a maioria (44\% de $1^{\underline{a}}$ a $4^{\underline{a}}$ e $57 \%$ de $5^{\underline{a}}$ a $8^{\underline{a}}$ ), todos os conteúdos podem ser relacionados ao ensino de CTS. Vale lembrar, contudo, que o significado de "todos" de $1^{\text {a }}$ a $4^{\text {a }}$ séries contempla todas as disciplinas do núcleo comum, enquanto que o "todos" de 5a a 8a séries referese aos conteúdos de ciências e geografia, principalmente. Um tema destacado pelos professores, em geral, e também valorizado pelos estudiosos de CTS (Solomon, 1993) é a questão ambiental.

Nos quadros 1 e 2, aparece um detalhamento dos conteúdos relacionados pelos professores. No primeiro, séries iniciais, os aspectos vinculados à saúde do ambiente e do corpo são priorizados nos conteúdos. No segundo ( $5^{\mathrm{a}}$ a $8^{\mathrm{a}}$ ), além de conteúdos relacionados ao ambiente e ao corpo humano, são lembrados conteúdos decorrentes do desenvolvimento tecnológico (clonagem, eletricidade, utilidade das máquinas no cotidiano, química dos alimentos, tecnologia ambiental etc.). Observamos, também, que os professores de $5^{\text {a }}$ a $8^{\text {a }}$ séries detalham mais os conceitos científicos quando se referem à relação entre conteúdos e ensino de CTS.

Ao estabelecermos relação entre essas respostas e o que é proposto pelos estudiosos de CTS e alfabetização científica, podemos considerar que muitos dos conteúdos listados estão próximos aos objetivos e preocupações da educação científica alinhados à CTS.

No quadro 3, especificamos as respostas dos professores da área científica do ensino médio à pergunta sobre a relação entre os conteúdos escolares e CTS (pergunta 2.2, anexo 1). Lembramos, no entanto, que, além desses 17 professores (70\%), outros 6 de outras áreas responderam ao questionário, perfazendo um total de 24. Do total de respondentes desse grau de ensino, 73\% também afirmaram que todos os conteúdos (ou a maioria) podem ser vinculados à CTS. Dos professores da área científica, 50\% eram de Biologia; 20\%, de Química e somente 5\%, de Física. 
O quadro apresenta uma síntese das respostas dos professores. Nelas, podemos constatar que, em geral, o ensino de CTS diz respeito ao vivido, a problemas e soluções que afetam o ambiente e a saúde humana, de modo positivo ou negativo. As respostas indicam como os professores com formação específica de ciências fazem referências ao processo de produção do conhecimento científico, relacionando-o à sociedade e à tecnologia.

\section{Quadro 3 - Relação entre conteúdos escolares e CTS citados pelos professores do ensino médio}

\begin{tabular}{|c|c|c|}
\hline Biologia $=12$ & Química $=4$ & Física $=2$ \\
\hline $\begin{array}{l}\text { Todos os conteúdos. } \\
\text { Ciência é uma atividade } \\
\text { humana sujeita a influência } \\
\text { e impactos sociais; o } \\
\text { aspecto tecnológico é } \\
\text { parceiro da ciência no } \\
\text { processo de conhecimento. }\end{array}$ & $\begin{array}{l}\text { Todos conteúdos - Químical } \\
\text { necessidade que o homem } \\
\text { tem de resolver seus } \\
\text { problemas orgânicos ou } \\
\text { não). }\end{array}$ & Física aplicada e energia. \\
\hline $\begin{array}{l}\text { Todos os conteúdos. } A \\
\text { tecnologia como parte } \\
\text { integrante da vida, e tudo } \\
\text { que diz respeito à vida diz } \\
\text { respeito à sociedade. }\end{array}$ & $\begin{array}{l}\text { A maior parte dos } \\
\text { conteúdos. Porém, parece } \\
\text { estar fora do controle social. }\end{array}$ & $\begin{array}{llr}\text { Conceitos } & \text { ligados } & \text { à } \\
\text { energia } & e & \text { sua } \\
\text { conservação, } & \text { evolução da } \\
\text { física. } & & \end{array}$ \\
\hline $\begin{array}{lr}\text { Todos os } & \text { conteúdos } \\
\text { quando abordados de uma } \\
\text { forma } & \text { dinâmica, } \\
\text { privilegiando } & \text { aspectos da } \\
\text { natureza, aplicação no } & \text { notidiano, solução de } \\
\text { cotioblemas, } & \text { participação } \\
\text { problemo } & \\
\text { ativa no meio. }\end{array}$ & $\begin{array}{l}\text { Conteúdos estão mais para } \\
\text { ciências, relacionados com a } \\
\text { tecnologia e a sociedade nos } \\
\text { pontos em que se passou } \\
\text { pela vivência. }\end{array}$ & \\
\hline Todos os conteúdos. & $\begin{array}{l}\text { lnterferência de substâncias } \\
\text { e misturas no meio } \\
\text { ambiente. }\end{array}$ & \\
\hline \multicolumn{3}{|l|}{ Quase todos. } \\
\hline $\begin{array}{lr}\text { Genética }\left(3^{\circ}\right. & \text { ano) } \\
\text { melhoramento } & \text { genético, } \\
\text { plantas, } & \text { animais; } \\
\text { importância da } & \text { medicina; } \\
\text { questão ética. (interfere na } \\
\text { cultura, no pensamento, na } \\
\text { opinião da sociedade). }\end{array}$ & & \\
\hline Ecologia, pesquisas de & & \\
\hline
\end{tabular}




\begin{tabular}{|c|c|c|}
\hline $\begin{array}{l}\text { doenças e genética. } \\
\text { Qualquer conteúdo de } \\
\text { biologia (não tão evidente } \\
\text { a princípio). }\end{array}$ & & \\
\hline \begin{tabular}{lrr} 
Conteúdos de ecologia, \\
seres vivos e & química, \\
mais & \multicolumn{2}{c}{ facilmente } \\
relacionados & com & o \\
cotidiano do aluno er com \\
fatos que ocorrem no, \\
meio, científico \\
tecnológico.
\end{tabular} & & 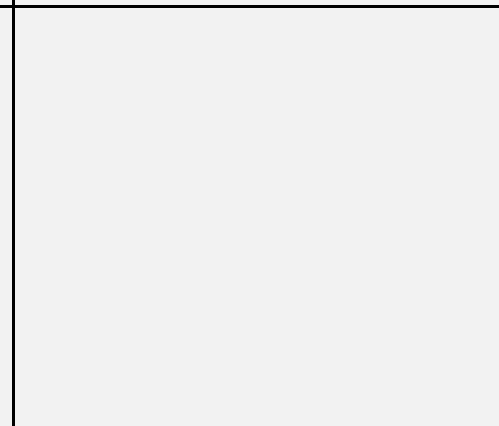 \\
\hline $\begin{array}{lrr}\text { Noções de } & \text { Química: } \\
\text { criação de } & \text { novas } \\
\text { substâncias que irão } \\
\text { facilitar a vida do }\end{array}$ & & \\
\hline $\begin{array}{l}\text { Na Química. Os aspectos } \\
\text { histórico e social em } \\
\text { relação aos aspectos } \\
\text { apresentados. }\end{array}$ & & \\
\hline $\begin{array}{l}\text { Instrumentos ópticos e } \\
\text { eletrônicos sofisticados } \\
\text { que possibilitam entender } \\
\text { melhor o funcionamento de } \\
\text { organismos, com utilização } \\
\text { de fundamentos da área de } \\
\text { saúde. }\end{array}$ & & \\
\hline
\end{tabular}

Em termos de recursos didáticos para o desenvolvimento das aulas, além do livro, adotado assumidamente por 17 deles (15\%), os professores referem-se, com mais freqüência, ao uso de artigos de revistas e jornais (dominando as revistas). Das revistas assinaladas, vale destacar: Globo Ciência, Superinteressante, Revista Nova Escola, Veja, Cadernos do 3o Mundo. Há indicação de uso de vídeo (Série Cosmos), realização de experiências simples, elaboração de modelos, pesquisa em bibliotecas, visitas a museus, postos de saúde, Jardim Botânico, planetário, caminhadas em áreas verdes e assentamentos agrícolas.

Sobre a relação desses conteúdos com a CTS, vale aqui a reflexão crítica de uma professora de escola pública:

“(...)O ensino de ciências tem-se limitado à transmissão de uma série de conceitos para simples memorização, não se articulando com os grandes avanços obtidos pela ciência e que são bombardeados quase que diariamente através da mídia. Apesar da precária 
situação do ensino público, tais recursos didáticos, quando contextualizados numa boa prática pedagógica, podem funcionar para estabelecer o nexo entre esta ciência proposta pelos currículos e o desenvolvimento da ciência e tecnologia que cresce a uma velocidade extraordinária e invade a vida de todos os cidadãos. Sendo assim, a utilização de artigos científicos pode ser o ponto de partida para a busca de sua fundamentação, encontrada nos conteúdos abordados em aula, ou, ao contrário, a partir de conteúdos discutidos, caminhar no sentido de sua aplicabilidade, tendo como apoio tais artigos científicos... A experimentação visa que o aluno vivencie o método científico elaborando hipóteses, organizando a atividade, estabelecendo conclusões, diferentemente da idéia de experimentação apresentada como receita de bolo... De posse dos princípios fundamentais da ciência, articulando-os e aplicando-os, os alunos poderão compreender sobre os grandes eventos realizados nesta área,... passando a exercer o seu papel de cidadãos, posicionando-se e decidindo criticamente diante deles."

Da ligação entre a Química e CTS, destacamos o seguinte depoimento:

“(...) quando falo das substâncias químicas presentes nos alimentos, levo os alunos a questionarem sobre a fome... levo-os à reflexão também sobre a questão do desperdício de alimentos, e então falo sobre as alternativas para aproveitamento desses alimentos."

Além da aplicação do questionário, fizemos um trabalho voltado para identificação da relação CTS nos ensinos formal (escola) e não-formal (museu), em duas etapas. Na primeira, oferecemos uma palestra seguida de uma dinâmica para cerca de 70 professores da Zona Oeste do Rio de Janeiro, sobre alfabetização científica. Na dinâmica, trabalhamos com o tema "Tempo" de duas maneiras. Primeiro, solicitando aos professores que escrevessem e representassem em desenho o significado da palavra tempo. Algumas das respostas estão aqui reproduzidas:

No segundo momento da dinâmica, distribuímos algumas crônicas sobre o tempo (Lightman, 1966). Os professores, divididos em grupo, leram, discutiram e apresentaram considerações sobre as leituras. Dos comentários finais, selecionamos um bastante significativo:

“(...) Até Newton, você tem uma idéia de tempo absoluto, de um tempo que pode ser dito, codificado e é sempre o mesmo em qualquer lugar. Com Einstein, você tem uma nova idéia de tempo, nesse sentido, e mais influenciado por outras pessoas, uma idéia de que o tempo é relativo, que a massa e o espaço são relativos e que se influenciam. Isso também vai influenciar como vamos pensar a questão do tempo. Infelizmente, nas escolas, trabalham muito pouco com as idéias da física mais moderna... Existe muito medo da física de Einstein, e esse texto pode dar pistas também para trabalharmos essa questão. Essa questão da velocidade, a velocidade da informação; quem não tem acesso rápido à informação está alienado, não sabe o que está acontecendo. Existe o computador que acessa a Internet e tem como se comunicar com o mundo inteiro. 
Quem não tem acesso a isso está perdendo nesse mundo da mesma forma que aqueles que têm fome, que aqueles que não têm salário digno."

\section{CTS NO ENSINO NÃO-FORMAL}

A pesquisa, no Museu de Ciência (Mast/MCT), foi realizada em duas fases. Na primeira, foram feitas observações de turmas (11 no total) que visitaram o museu. Na segunda, foi realizado um seminário dando continuação à discussão sobre o conceito de tempo, anteriormente explorado. Foram convidados todos os professores (70) que participaram do $1^{\circ}$ seminário, mas somente 18 compareceram.

\section{A visita}

O quadro 4 apresenta uma caracterização geral dos visitantes. Destacamos nele a forma como os professores são inseridos no contexto do Mast: a maioria leva as turmas após passar por um treinamento para compreender a proposta e poder colaborar no dia da visita.

\section{Quadro 4 - Caracterização dos visitantes escolares ao Mast}

\begin{tabular}{|c|c|c|c|c|}
\hline SÉRIE & ESCOLA & $\begin{array}{l}\text { FORMAÇÃO DO } \\
\text { PROFESSOR }\end{array}$ & $\begin{array}{c}\text { ENTRADA NO } \\
\text { Mast }\end{array}$ & MOTIVO DA VISITA \\
\hline \multirow[t]{2}{*}{ 3a Série } & Particular & $\begin{array}{l}\text { Administração } \\
\text { Pedagogia }\end{array}$ & Treinamento & $\begin{array}{l}\text { Fixar a matéria } \\
\text { (Planetas) }\end{array}$ \\
\hline & Particular & $\begin{array}{ll}\text { Matemática } & \text { e } \\
\text { Pedagogia } & \end{array}$ & Treinamento & $\begin{array}{l}\text { Por estar dando o } \\
\text { conteúdo e pela } \\
\text { curiosidade } \\
\text { crianças }\end{array}$ \\
\hline \multirow[t]{2}{*}{$4^{a}$ Série } & Particular & Sem informação & Treinamento & \begin{tabular}{llr} 
Matéria & \multicolumn{2}{r}{ dada } \\
(astros para & a \\
criança & ver & no \\
concreto) & &
\end{tabular} \\
\hline & Particular & Pedagogia e Letras & Conta própria & $\begin{array}{l}\text { Para visualizar o } \\
\text { que é dado em sala }\end{array}$ \\
\hline \multirow[t]{3}{*}{ 5a Série } & Particular & Biologia & Treinamento & Sem informação \\
\hline & Particular & $\begin{array}{l}\text { Supervisora em Artes } \\
\text { e Psicologia }\end{array}$ & $\begin{array}{l}\text { Sem } \\
\text { informação }\end{array}$ & Sem informação \\
\hline & Particular & História e Geografia & $\begin{array}{l}\text { Sem } \\
\text { informação }\end{array}$ & Sem informação \\
\hline
\end{tabular}




\begin{tabular}{|c|c|c|c|c|}
\hline SÉRIE & ESCOLA & $\begin{array}{l}\text { FORMAÇÃO DO } \\
\text { PROFESSOR }\end{array}$ & $\begin{array}{c}\text { ENTRADA NO } \\
\text { Mast }\end{array}$ & MOTIVO DA VISITA \\
\hline \multirow[t]{2}{*}{$\begin{array}{l}\text { Mistas } \\
\left(3^{\underline{a}} \text { e } 4^{\underline{a}}\right)\end{array}$} & Particular & $\begin{array}{l}\text { Especialização em } \\
\text { Literatura }\end{array}$ & Treinamento & $\begin{array}{l}\text { Trabalhar conteúdos } \\
\text { (começa em espaço } \\
\text { e termina em } \\
\text { Microcosmo) }\end{array}$ \\
\hline & Particular & $\begin{array}{l}\text { Psicologia } \\
\text { Pedagogia }\end{array}$ & Treinamento & $\begin{array}{l}\text { Trabalhar conteúdo } \\
\text { (Universo) e para } \\
\text { sair do abstrato. }\end{array}$ \\
\hline \multirow[t]{2}{*}{$\begin{array}{l}\text { Mistas } \\
\left(2^{\underline{a}}, \quad 3^{\underline{a}} \quad\right. \\
\left.4^{\underline{a}}\right)\end{array}$} & Particular & Pedagogia & Treinamento & $\begin{array}{l}\text { Está dando } 0 \\
\text { conteúdo }\end{array}$ \\
\hline & $\begin{array}{l}\text { Pública } \\
\text { Municipal }\end{array}$ & Pedagogia & $\begin{array}{l}\text { Sem } \\
\text { informação }\end{array}$ & Sem informação. \\
\hline
\end{tabular}

Das 11 turmas que visitaram o Mast, 10 eram de escolas particulares. Vale ainda destacar que a maioria dos professores, além de não pertencer à área de ciências, costuma levar os alunos para fixar conteúdos com que estão trabalhando em sala de aula.

As observações ficaram restritas a uma parte da exposição permanente. Nessa exposição, Quatro Cantos de Origem, o Mast se propõe a desenvolver as noções de tempo e espaço a partir das narrativas tradicionais (mito) e das narrativas modernas (científicas).A "musealização do acervo constitui-se como meio eficiente de enriquecimento da aprendizagem científica, uma vez que parte do pressuposto de que o público que o visita já detém informações preliminares sobre o que vai encontrar" (MAST, 1992).

O museu pretende ser uma espécie de contexto-síntese do debate mito, ciência e tecnologia ao confrontar os dois primeiros e ao expor provas materiais dos avanços científico e tecnológico (relógios, lunetas, telescópios, mapas celestes etc.). Além de permitir um aprofundamento do deslocamento do modelo geocêntrico e sua substituição pelo modelo heliocêntrico, das noções de tempo circular e linear, de espaço e tempo limitados e infinitos, a integração do que se aprende na escola com o que o museu possibilita ver e aprofundar permite, inclusive, perceber de que modo fragmentos das narrativas primitivas permanecem nos modelos e nas concepções científicas:

"(...) O Zodíaco, este conjunto de estrelas distribuídas numa faixa do céu, aparece como um elemento importante para se definir o tempo. Grupo de estrelas do Zodíaco foi associado às figuras que transpunham, de forma simbólica, elementos terrestres para o céu.(...) A ciência moderna teve sua base fundada na observação astronômica. Durante o século XVII, as tabelas astronômicas servem de base para a formulação da física. $O$ céu simbólico serve de meio para refletir sobre o homem e seus ciclos. Homem e Universo integram-se".(MAST, 1992: 25). 
O quadro a seguir apresenta uma síntese das reações das turmas quando visitaram a exposição permanente. Lembramos que a coleta dessas observações foi feita por duas bolsistas, que registravam as reações dos visitantes em um formulário próprio (anexo 3), durante o período de duração da visita - uma hora. Foram realizadas 12 observações em um período de quatro meses, somente na parte da exposição permanente que aborda a relação CTS por meio da evolução do conceito de espaço e tempo.

\section{Quadro 5 - Reações das turmas em visita à exposição permanente}

\begin{tabular}{|c|c|c|c|}
\hline SÉRIE & $\begin{array}{c}\text { SALA BRANCA } \\
\text { (Modelo Geocêntrico). }\end{array}$ & $\begin{array}{c}\text { SALAS INTERMEDIÁRIAS } \\
\text { (Modelo Heliocêntrico) }\end{array}$ & $\begin{array}{l}\text { SALA ESCURA } \\
\text { (Visão do céu a } \\
\text { partir da Terra) }\end{array}$ \\
\hline $\begin{array}{l}3^{a} \text { Série } \\
(2 \text { e } 4)\end{array}$ & $\begin{array}{l}\text { № 2: O monitor estimula as } \\
\text { crianças a falar das imagens } \\
\text { que podem retratar as } \\
\text { estações do ano. Também } \\
\text { menciona a inclinação da } \\
\text { Terra, além de chamar a } \\
\text { atenção para a imagem do } \\
\text { mês de fevereiro, no qual está } \\
\text { nevando. As crianças dizem } \\
\text { que deve ser em outro país e } \\
\text { não no Brasil. } \\
\text { № 4: A professora começol } \\
\text { explicando o livro das horas, } \\
\text { reforçou a explicação dos } \\
\text { STONEHENGE, falando do } \\
\text { pôr-do-sol, como também do } \\
\text { sistema geocêntrico. } A \\
\text { professora pergunta para os } \\
\text { alunos por que, no mês de } \\
\text { fevereiro, seria inverno no } \\
\text { continente europeu. Os } \\
\text { alunos rapidamente } \\
\text { responderam: "Por causa da } \\
\text { vestimenta." }\end{array}$ & $\begin{array}{l}\text { № 2: As crianças observar } \\
\text { atentamente a parte dos } \\
\text { descobrimentos. Percebem } \\
\text { o quanto é perigoso tentar } \\
\text { observar o Sol com luneta, } \\
\text { lupa etc. Averiguam que é } \\
\text { muito mais fácil usar um } \\
\text { astrolábio para medir as } \\
\text { estrelas. Ao chegar à parte } \\
\text { do sistema solar, falam dos } \\
\text { planetas (tudo decorado). } \\
\text { № } 4: \quad \text { As crianças } \\
\text { respondem atentamente à } \\
\text { rota dos descobrimentos. } \\
\text { No diálogo, a professora } \\
\text { relembra uma das suas } \\
\text { aulas e pede que alguma } \\
\text { criança exponha o que já } \\
\text { foi visto. Explica também } \\
\text { como foi difícil Galileu } \\
\text { convencer os outros } \\
\text { (mostra o diálogo). No } \\
\text { sistema solar, uma das } \\
\text { crianças menciona que a } \\
\text { Terra está girando muito } \\
\text { rápido. O monitor explica } \\
\text { que é só uma órbita } \\
\text { imaginária. }\end{array}$ & $\begin{array}{l}\text { № 2: As crianças sć } \\
\text { fizeram ligações com } \\
\text { os signos. } \\
\text { № 4: Ao entrarem né } \\
\text { sala, as crianças } \\
\text { procuram logo seus } \\
\text { signos. A professora } \\
\text { pediu que as crianças } \\
\text { observassem a escala } \\
\text { dos meses e o melhor } \\
\text { período para ver as } \\
\text { constelações de cada } \\
\text { signo. }\end{array}$ \\
\hline $\begin{array}{l}4^{a} \text { Sériє } \\
\text { (7e 8) }\end{array}$ & $\begin{array}{l}\text { № 7: As crianças observaram } \\
\text { que havia alguma coisa }\end{array}$ & $\begin{array}{|lcrr|}\text { № } & \text { 8: } & \text { Os } & \text { alunos } \\
\text { manuseiam } & 0 & \text { astrolábio. }\end{array}$ & $\begin{array}{lr}\text { № } 8: & \text { As crianças } \\
\text { ficaram } & \text { observando }\end{array}$ \\
\hline
\end{tabular}




\begin{tabular}{|c|c|c|c|}
\hline & 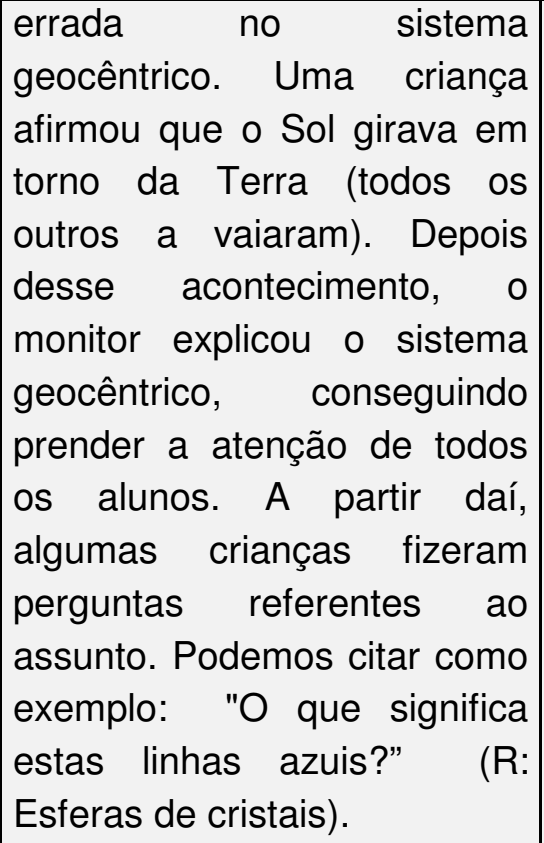 & $\begin{array}{l}\text { Na parte dos planetas, eles } \\
\text { falam seus nomes na sua } \\
\text { devida seqüência. }\end{array}$ & $\begin{array}{l}\text { as constelações, só } \\
\text { depois perceberam os } \\
\text { signos. }\end{array}$ \\
\hline $\begin{array}{l}5^{a} \text { Série } \\
(9,10 \\
\text { e 11) }\end{array}$ & 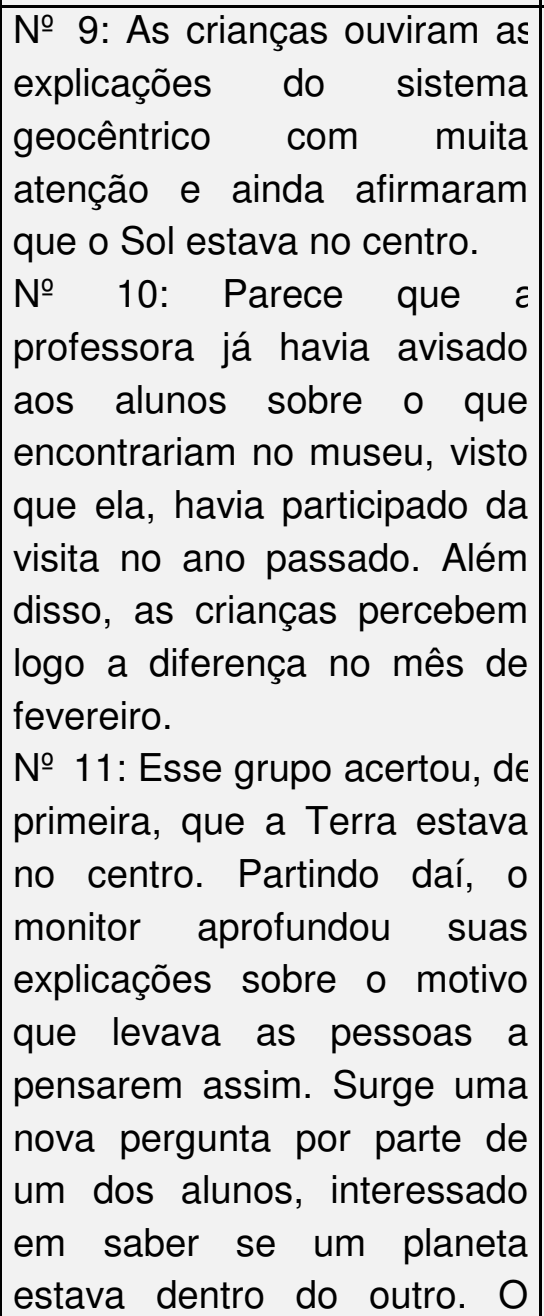 & $\begin{array}{l}\text { № 9: As crianças falam dos } \\
\text { descobrimentos. Logo em } \\
\text { seguida, o monitor vai para } \\
\text { a parte do sistema solar. } \\
\text { Novamente aparece a } \\
\text { "decoreba" da ordem dos } \\
\text { planetas. } \\
\text { № 10: Um aluno perguntol } \\
\text { ao monitor se Cabral tinha } \\
\text { descoberto o Brasil na } \\
\text { mesma época em que } \\
\text { Colombo descobriu a } \\
\text { América. Outro aluno } \\
\text { questionou o fato de } \\
\text { Fernão de Magalhães ser o } \\
\text { primeiro a dar a volta ao } \\
\text { mundo, visto que, se } \\
\text { chegou morto, não poderia } \\
\text { tê-lo feito. } \\
\text { № 11: As crianças } \\
\text { manipulam a parte das } \\
\text { rotas dos descobrimentos. } \\
\text { Na parte do sistema solar, } \\
\text { uma criança percebe que } \\
\text { os planetas mais próximos }\end{array}$ & $\begin{array}{l}\text { № 9: As crianças } \\
\text { ficaram fascinadas } \\
\text { com as figuras das } \\
\text { constelações e com o } \\
\text { fato de encontrarem } \\
\text { seu signo. } \\
\text { № 11: As crianças } \\
\text { tiveram dificuldade de } \\
\text { encontrar seus signos, } \\
\text { talvez por não terem } \\
\text { conhecimentos de } \\
\text { "latim”. }\end{array}$ \\
\hline
\end{tabular}




\begin{tabular}{|c|c|c|c|}
\hline & $\begin{array}{l}\text { monitor esclareceu que as } \\
\text { esferas é que estavam uma } \\
\text { dentro da outra. }\end{array}$ & do Sol giram mais rápido. & \\
\hline $\begin{array}{l}\text { Mistas } \\
-3^{a} \quad \epsilon \\
4^{a} \\
\text { séries } \\
(3 \text { e } 6)\end{array}$ & $\begin{array}{l}\text { № 3: O monitor incentiva as } \\
\text { crianças a perguntarem. Elas } \\
\text { respondem o que é } \\
\text { calendário; percebem as } \\
\text { diferenças entre os meses no } \\
\text { Brasil e na Europa. Na parte } \\
\text { em que é exposta a distância } \\
\text { entre a Terra e o Sol, a } \\
\text { professora pede explicação } \\
\text { ao monitor. Ela faz ligação da } \\
\text { geometria com a astronomia, } \\
\text { mencionando que já havia } \\
\text { dado a matéria de triângulos } \\
\text { e ângulos. }\end{array}$ & $\begin{array}{l}\text { № 6: As crianças nãc } \\
\text { estavam } \\
\text { interessadas em ouvir e, } \\
\text { sim, em ver e explorar } \\
\text { todos os cantos com } \\
\text { liberdade. Só deram mais } \\
\text { atenção à explicação do } \\
\text { astrolábio. Na hora do } \\
\text { sistema solar, as crianças } \\
\text { não sabiam a seqüência. } \\
\text { Arriscavam os nomes; } \\
\text { pareciam não conhecer os } \\
\text { planetas. }\end{array}$ & 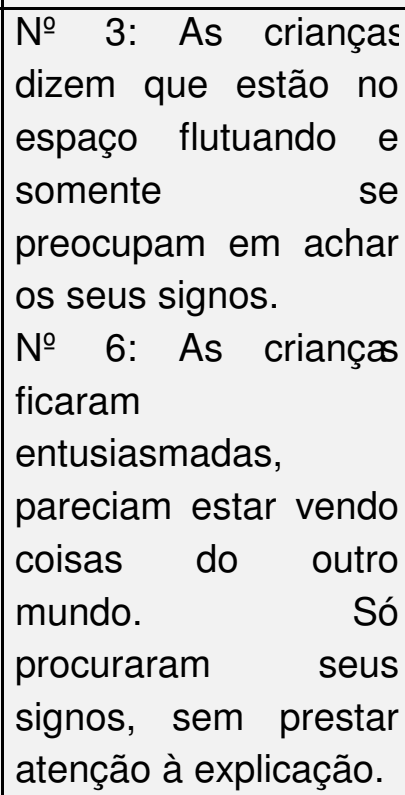 \\
\hline $\begin{array}{l}\text { Mistas } \\
-\quad 2^{a}, 3^{a} \\
e \quad 4^{a} \\
\text { séries } \\
(5 \text { e } 11)\end{array}$ & 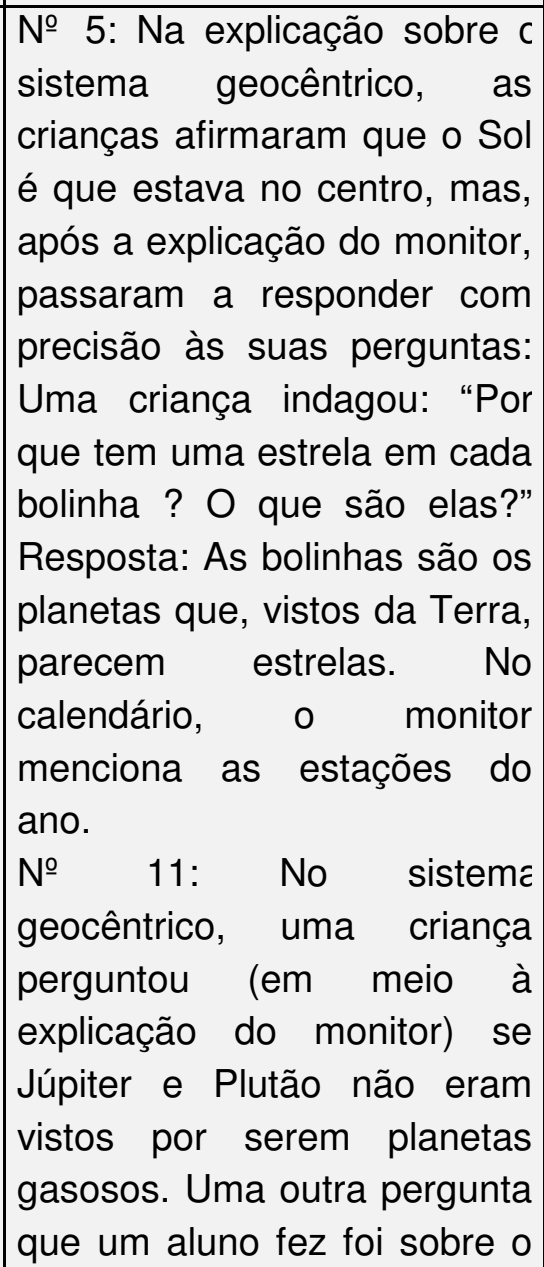 & $\begin{array}{l}\text { № 5: As crianças falam } \\
\text { sobre os descobrimentos, } \\
\text { observam o astrolábio e, } \\
\text { na parte dos planetas, não } \\
\text { sabem a ordem, mas ficam } \\
\text { muito interessadas pela } \\
\text { luneta astronômica. } \\
\text { № 11: As crianças } \\
\text { observam o quadro das } \\
\text { rotas, manipulam o } \\
\text { astrolábio, ficam } \\
\text { encantadas olhando para o } \\
\text { sistema solar e percebem } \\
\text { que os planetas mais } \\
\text { próximos do Sol giram } \\
\text { mais rápido que os mais } \\
\text { afastados. }\end{array}$ & $\begin{array}{l}\text { № 5: As crianças se } \\
\text { atrapalharam na } \\
\text { procura dos signos, } \\
\text { mas ao encontrá-los } \\
\text { tiveram curiosidade } \\
\text { em observar as } \\
\text { constelações. } \\
\text { № 11: As crianças } \\
\text { procuraram logo o seu } \\
\text { signo. }\end{array}$ \\
\hline
\end{tabular}




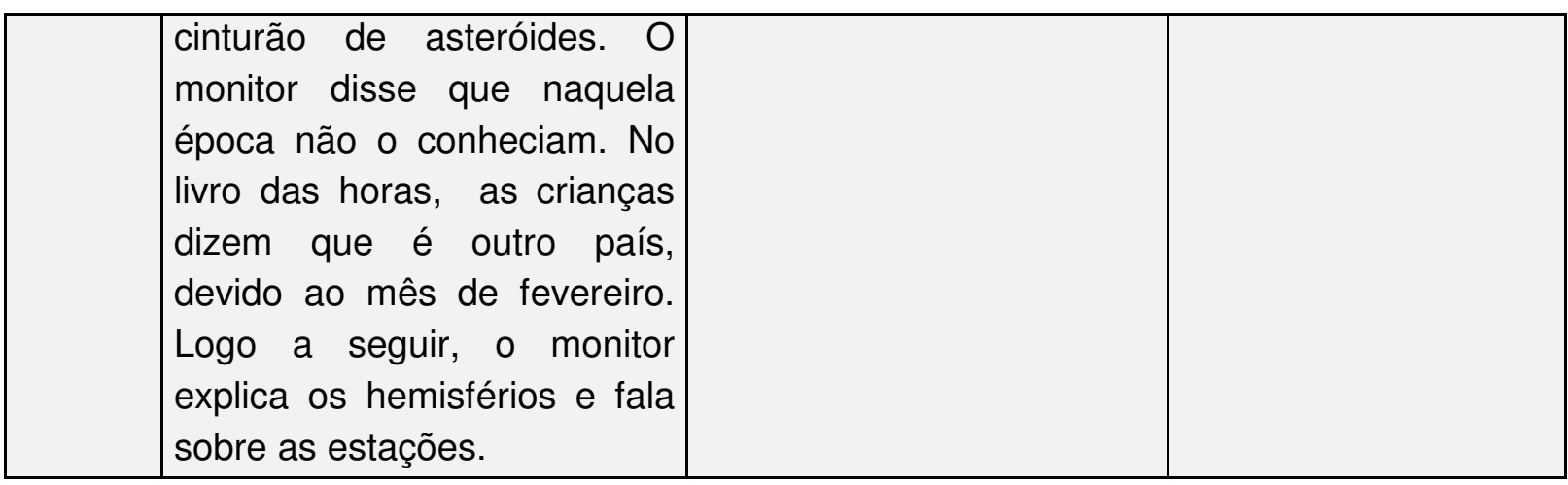

Por esse quadro, é possível dizer que a visita ao museu expõe professores e alunos a um conflito que resulta do fato de o museu e a escola trabalharem os mesmos temas de modo bastante diferenciado, pois, enquanto os professores trabalham os conteúdos de modo descontextualizado, a exposição contextualiza e ressalta a história da ciência. Pelo fato de o museu ter uma exposição que busca articular CTS, ele se encontra mais próximo de um projeto de alfabetização científica do que a escola. O quadro 6 confirma essa observação, especialmente quando registra que, em geral, os alunos não sabem que o modelo geocêntrico antecedeu o modelo heliocêntrico. Por meio dele também é possível constatar dois outros aspectos significativos. O primeiro deles é a preocupação da exposição em passar certas noções de tempo e de espaço com as quais os alunos não estão ainda familiarizados. $O$ segundo refere-se à identificação dos alunos com a perspectiva mítica (astrologia), quando visitam a sala escura. Desse modo revela-se, para alunos e professores, a possibilidade, através do ensino não-formal, de se trabalhar mais próximo da articulação CTS pela via da narrativa, do mito, da ciência. Vale destacar que a questão tecnológica, mesmo estando presente na exposição permanente, não é suficientemente percebida e trabalhada pelos professores e monitores.

Quadro 6 - Reações em face dos modelos geocêntrico e heliocêntrico

\begin{tabular}{|c|c|c|c|}
\hline Série & Sala Branca & Sala Intermediária & Sala Escura \\
\hline $4^{a}$ Sérè & $\begin{array}{l}\text { As explicações centram- } \\
\text { se no sistema } \\
\text { geocêntrico. }\end{array}$ & $\begin{array}{l}\text { A visita às salas é corrida. } \\
\text { Destacam-se o manuseio do } \\
\text { astrolábio e a ordem correta } \\
\text { da nomeação dos planetas. }\end{array}$ & $\begin{array}{l}\text { Observação } \\
\text { signos e } \\
\text { constelações. }\end{array}$ \\
\hline 5a Série & $\begin{array}{l}\text { As explicações centram- } \\
\text { se no sistema } \\
\text { geocêntrico, mas os } \\
\text { alunos incorrem no erro } \\
\text { explicativo sobre o } \\
\text { modelo (vêem o Sol no } \\
\text { centro). }\end{array}$ & $\begin{array}{l}\text { Novamente } r \text { explicação } \\
\text { relacionando } \\
\text { descobrimentos (História) com } \\
\text { as novas possibilidades de } \\
\text { visão e conhecimento do } \\
\text { Universo (Ciências). Destaque } \\
\text { para a observação de uma } \\
\text { criança sobre movimentos }\end{array}$ & $\begin{array}{lr}\text { As } & \text { crianças } \\
\text { observam, } & \\
\text { "fascinadas", } & \text { as } \\
\text { constelações e os } \\
\text { signos. } & \text { Revelam } \\
\text { dificuldade } & \text { com o } \\
\text { latim e, por isso, } \\
\text { demoram } & \text { a }\end{array}$ \\
\hline
\end{tabular}




\begin{tabular}{|c|c|c|c|}
\hline & & $\begin{array}{l}\text { mais rápidos dos planetas } \\
\text { mais próximos do Sol. }\end{array}$ & $\begin{array}{l}\text { identificar seu signo } \\
\text { respectivo. }\end{array}$ \\
\hline $\begin{array}{l}\text { Séries } \\
\text { Mistas }\end{array}$ & $\begin{array}{l}\text { Tanto discutem os } \\
\text { modelos } \\
\text { incorrem no erro de } \\
\text { afirmar que o Sol está } \\
\text { no centro do modelo } \\
\text { geocêntrico) quanto as } \\
\text { estações do ano e a } \\
\text { impossibilidade de se } \\
\text { ver a época certa dos } \\
\text { planetas. Um aluno (no } \\
\text { 12) busca explicação } \\
\text { própria para o fato de os } \\
\text { planetas (como Plutão) } \\
\text { não serem vistos (eram } \\
\text { gasosos). }\end{array}$ & $\begin{array}{l}\text { Trabalha-se a relação História } \\
\text { (descobrimento) e Ciências } \\
\text { (visão do céu). As crianças } \\
\text { observam o astrolábio, } \\
\text { nomeiam os planetas e notam } \\
\text { que os planetas mais } \\
\text { próximos do Sol giram mais } \\
\text { rápido (simulação do modelo } \\
\text { heliocêntrico); }\end{array}$ & $\begin{array}{l}\text { As crianças buscam, } \\
\text { principalmente, seu } \\
\text { signo. }\end{array}$ \\
\hline
\end{tabular}

Por ser o tempo uma dimensão relevante para a ciência e por ela estar destacada na exposição permanente, consideramos oportuno convidar alguns professores, que haviam discutido o tema em um dos cursos de extensão, para visitar o museu e rediscutir a temática por meio de um seminário.

\section{O seminário}

Os professores (18) que compareceram ao Museu de Astronomia assistiram num primeiro momento, a uma palestra que abordou a história da construção do calendário e as diferentes concepções de tempo ao longo da história da humanidade e de diferentes civilizações. A idéia era caracterizar a categoria tempo como uma construção humana e abordar questões abertas que ainda precisam ser resolvidas. Num segundo momento, visitaram a Casa da Hora, instituição vinculada ao Observatório Nacional e responsável pela determinação da hora local brasileira. Nessa instituição, um técnico responsável mostrou-lhes aparatos de medir o tempo com diferentes precisões.

Num terceiro momento, os professores percorreram, orientados por um técnico, os espaços que constituem a exposição permanente do Museu de Astronomia, podendo, então, observar como as relações espaço-tempo eram estabelecidas na Idade Média, durante o Renascimento e na Idade Moderna. A sala dedicada aos instrumentos de medida de tempo foi particularmente explorada. Num quarto momento, os professores foram convidados a escrever e apresentar em desenho, o significado da palavra tempo. Algumas das respostas estão aqui apresentadas.

Os quatro desenhos e as frases escolhidas para dar significado ao conceito de tempo entre professores ( $1^{\underline{a}}$ a $8^{\underline{a}}$ séries), comparados com os desenhos da primeira fase do trabalho, reproduzem as mesmas concepções sobre o tempo. Observa-se que o tempo da escola, 
também, está presente, e o tempo mecânico simbolizado pelo relógio permanece com dimensões existenciais. Em relação ao conceito de tempo ensinado, este está associado às equações do movimento e à linha do tempo.

Percebe-se, então, que os professores oscilam suas representações entre as apoiadas em pensamento paradigmático e pensamento narrativo e, quando se expressam por meio de pensamento paradigmático, utilizam-se de conteúdos escolares. Como a visita se dá num tempo curto, fica difícil obter informações sobre possíveis mudanças no conceito de tempo dos professores. Seria necessário, portanto, realizar um trabalho mais longo e contínuo junto a esses professores para perceber possíveis mudanças. Entretanto, fica claro como o pensar sobre a categoria tempo, expressa aqui por meio de desenhos, explicita as relações entre mito, ciência e tecnologia.

\section{CONCLUSÕES}

A discussão teórica com que iniciamos este artigo, envolvendo o movimento de CTS no ensino de ciências e os modos de pensamento narrativo e paradigmático, foi significativa para procedermos a uma avaliação do estado da educação científica na escola e no museu. Ela iluminou a construção dos instrumentos e a análise dos dados coletados, mostrando, por exemplo, que não há sintonia entre o ensino formal (predominantemente apoiado no pensamento paradigmático e distante do narrativo) e o ensino não-formal (mais propenso a uma articulação entre os dois modos de pensamento). Percebemos que, no caso do ensino não-formal apresentado pelo Mast, há uma tendência a incorporar mito e ciência na narrativa, possibilitando, assim, um aprendizado mais próximo das concepções do cotidiano. Por outro lado, há dificuldade por parte dos idealizadores em articular os elementos da tecnologia via narrativas apoiadas nos objetos. Essa dificuldade está contida na fala dos estudantes e dos professores, que discutem mais os modelos apresentados.

O uso das narrativas, no ensino de ciências, apresenta condições para explorar a relação CTS, na medida em que pode propiciar reflexões acerca dos aspectos éticos e epistemológicos da ciência e da tecnologia, além de dar a dimensão da presença da ciência e da tecnologia na sociedade.

A análise dos dados levantados nas escolas indica que, embora os professores ainda estejam atrelados ao ensino tradicional de ciências (em grande parte por determinação dos currículos, programas oficiais e livros didáticos), há por parte deles um esforço no sentido de trabalhar esses conhecimentos de modo menos fragmentado e, na medida do possível, mais próximo das realidades social e tecnológica. Atestam essas predisposições o uso de recursos como jornais, revistas, vídeos; o desenvolvimento de atividades como visitas a museus, postos de saúde, assentamentos agrícolas e o empenho em promover debates e reflexões que articulem ciência e tecnologia à nossa realidade.

No desenvolvimento da relação CTS, sob a ótica do conceito de tempo, nos contextos formal e não-formal de educação, seja nos cursos e seminários, seja nas visitas, tivemos a oportunidade de constatar como aparatos tecnológicos (relógios) reforçam determinados conceitos científicos, mas, por outro lado, como relações estabelecidas entre o tradicional e 0 moderno, o conhecimento abstrato e a reflexão existencial possibilitam uma perspectiva 
interdisciplinar do debate, em que as relações mito, ciência e tecnologia podem ser abordadas. A esse respeito, vale lembrar que as representações produzidas pelos professores sobre 0 conceito de tempo estão fundamentadas nos conceitos social e tecnológico, expressos nos desenhos do relógio mecânico, e que tende a encobrir a história desse conceito, tornando-o natural, o que é, na verdade, uma construção social do tempo.

Neste trabalho, fizemos um esforço no sentido de estabelecer um paralelo entre a educação científica formal e a não-formal disponível em escolas e no Museu de Ciências do Estado do Rio de Janeiro, para identificar a sua proximidade com uma das tendências do ensino de ciências: ensino de CTS. No museu, a pedagogia implementada articula as ações envolvendo espaço, objeto e tempo, pois nos museus as narrativas construídas em torno dos objetos que se dispõem em determinados espaços são apreendidas em tempo próprio pelos visitantes e de forma autônoma. As narrativas presentes no museu não estão necessariamente atreladas ao currículo escolar, permitindo ao seu elaborador escolhas diversificadas, tanto em relação aos conteúdos científicos como aos recursos comunicacionais.

Assim, constatamos que, apesar de ainda estarmos muito atrelados a um ensino fragmentado de ciências, a oferta educacional de um museu de ciências com uma proposta histórica e contextualizada da ciência pode contemplar uma educação em CTS. Embora no ensino formal, verifiquemos que os currículos, programas e livros didáticos, em sua maioria, ainda estão presos a uma visão científica fragmentada, observamos que os professores tendem a trabalhar, na sala de aula, alguns conteúdos que se aproximam da perspectiva de CTS.

Há, no entanto, necessidade de se aprofundarem as reformas de ensino de ciências, visando à ampliação da oportunidade de se trabalhar melhor a relação CTS e levando em conta, sobretudo, a essencial articulação entre os ensinos formal, não-formal e os meios de divulgação científica. O aprofundamento do estudo das narrativas abordando a relação mito, ciência e tecnologia poderia constituir um caminho interessante de integração entre o ensino formal, o não-formal e a divulgação científica. Essa perspectiva, além de nortear cursos de atualização de professores, poderia orientar as ações das instituições envolvidas com a educação científica, objetivando a ampliação da alfabetização científica.

\section{Agradecimentos}

As autoras agradecem à bolsista Fátima Pereira Duque (Pibic/CNPq/UFF) pela montagem dos Quadros 4, 5 e 6. 


\section{ANEXOS}

\section{Anexo 1 - Questionário de sondagem para professores:}

Universidade Federal Fluminense

Centro de Estudos Sociais Aplicados

Faculdade de Educação

Pesquisa CTS no contexto da alfabetização científica.

Prezado(a) professor(a),

Estamos solicitando a sua colaboração no sentido de responder às perguntas em anexo, o que muito contribuirá para sabermos como nossas escolas têm lidado, no ensino de ciências, com a relação CTS. Desde já agradecemos a sua valiosa colaboração.

1. Itens gerais de identificação:

A equipe da pesquisa

1.1. Tipo(s) de disciplina que leciona

1.2. Série(s) em que atua

1.3. Tempo de exercício do magistério

1.4. Tipo de escola em que trabalha: pública / particular

\section{Questões:}

2.1. Que tipos de conteúdo o senhor (a senhora) costuma desenvolver?

2.2. Desses conteúdos quais são, na sua opinião, aqueles em que estão presentes aspectos ligados à relação CTS? Por quê?

2.3. Que recursos didáticos costuma utilizar em suas aulas? Em que medida eles ajudam no processo de aprendizado dos conteúdos identificados com a relação CTS?

2.4. Qual (quais) o(s) livro(s) didático(s) que utiliza mais para desenvolver conteúdos de CTS? Como o senhor (a senhora) passou a utilizá-los?

3. Solicitação final: se o senhor (a senhora) dispõe de algum material produzido para transmitir ou avaliar conteúdos relativos a CTS (textos de aula, provas ou testes de alunos, trabalhos de aluno etc.), gostaríamos que anexasse um exemplar a este instrumento de pesquisa.

\section{Anexo 2 - Ficha de Observação MAST/CNPq}

\section{Formulário de observação: pesquisa CTS}

Sala:

Data: Hora:

Nome do bolsista: 
Explicações/ênfases Profs. e monitores

Dúvidas, questões e comentários de alunos

\section{Anexo 3 - Tabelas com informações sobre os professores}

Tabela 2 - Séries em que os professores atuam e disciplina que lecionam

\begin{tabular}{|c|c|c|c|c|c|}
\hline Nível de Ensino: & Fun & mental & Médio & Superio & total \\
\hline Disciplina: & $\begin{array}{l}\text { CA a } 4^{\mathrm{a}} \\
\text { série }\end{array}$ & $5^{\mathrm{a}}$ a $8^{\mathrm{a}}$ série & $1^{\frac{a}{a}}$ a $3^{\mathrm{a}}$ série & & \\
\hline Ciências e Biologia & 0 & 11 & 10 & 0 & 21 \\
\hline Química & 0 & 0 & 1 & 0 & 1 \\
\hline Química e Ciências & 1 & 2 & 2 & 0 & 5 \\
\hline Ciências & 2 & 16 & 0 & 0 & 18 \\
\hline $\begin{array}{l}\text { Educação Ambiental e } \\
\text { Ciências }\end{array}$ & 0 & 1 & 0 & 0 & 1 \\
\hline Física & 0 & 0 & 1 & 0 & 1 \\
\hline $\begin{array}{l}\text { Ciências, Biologia, } \\
\text { Programa de Saúde }\end{array}$ & 0 & 1 & 1 & 0 & 2 \\
\hline $\begin{array}{l}\text { Ciências e Programa de } \\
\text { Saúde }\end{array}$ & 0 & 1 & 0 & 0 & 1 \\
\hline $\begin{array}{l}\text { Química, Física e } \\
\text { Matemática }\end{array}$ & 0 & 1 & 1 & 0 & 2 \\
\hline $\begin{array}{l}\text { Português, Estudos } \\
\text { Sociais, Matemática e } \\
\text { Ciências }\end{array}$ & 4 & 1 & 2 & 0 & 7 \\
\hline Ecologia e Biologia & 0 & 1 & 1 & 0 & 2 \\
\hline Todas - Núcleo Comum & 20 & 0 & 0 & 0 & 20 \\
\hline $\begin{array}{l}\text { Biologia, Ciências e } \\
\text { Programa de Saúde }\end{array}$ & 0 & 1 & 0 & 0 & 1 \\
\hline Física e Matemática & 0 & 1 & 1 & 1 & 3 \\
\hline Outras & 4 & 9 & 4 & 0 & 17 \\
\hline TOTAL & $\overline{31}$ & 46 & 24 & 1 & 102 \\
\hline
\end{tabular}

Obs: CA - Ciclo de Alfabetização, que corresponde à $1^{\text {a }}$ e $2^{\underline{a}}$ séries do Ensino Fundamental 
Tabela 3 - Séries em que os professores atuam e tipo de escola em que trabalham

\begin{tabular}{|c|c|c|c|c|c|c|}
\hline $\begin{array}{r}\text { Nível de } \\
\text { Ensino: } \\
\text { Tipo de Escola: }\end{array}$ & Fund & ental & Médio & Superior & $\begin{array}{c}\text { Educaçã } \\
0 \\
\text { Especial }\end{array}$ & total \\
\hline & $\begin{array}{l}\text { CA à } 4^{\underline{a}} \\
\text { série }\end{array}$ & $\begin{array}{l}5^{\mathrm{a}} \text { à } 8^{\mathrm{a}} \\
\text { série }\end{array}$ & $\begin{array}{l}1^{\mathrm{a}} \text { à } 3^{\mathrm{a}} \\
\text { série }\end{array}$ & - & - & - \\
\hline Pública & 27 & 36 & 13 & 1 & 1 & 78 \\
\hline Particular & 3 & 2 & 4 & 0 & 0 & 9 \\
\hline $\begin{array}{l}\text { Pública/Particul } \\
\text { ar }\end{array}$ & 2 & 8 & 7 & 0 & 0 & 17 \\
\hline Outras & 1 & 0 & 0 & 0 & 0 & 1 \\
\hline total & 33 & 46 & 24 & 1 & 1 & 105 \\
\hline
\end{tabular}

\section{REFERÊNCIAS BIBLIOGRÁFICAS:}

Angotti, J. A. P. 1991. Fragmentos e Totalidades do Conhecimento Científico e do Ensino de Ciências. São Paulo: Faculdade de Educação da USP. (Tese, Doutorado).

ARONS, A. B. 1983. Achieving Wider Scientific Literacy. Daedalus, n.112, p. 91-121.

AULER, D., Stueder, D. M., CUNHA, Marcio B. O enfoque ciência-tecnologia-sociedade como parâmetro e motivador de alterações curriculares. In: ENCONTRO NACIONAL DE PESQUISA EM ENSINO DE CIÊNCIAS, 1, 1997, Águas de Lindóia - SP. Atas... Porto Alegre: Instituto de Física - UFRGS, 1997. p. 187-192.

BARROS, S. S. 1990. O Acidente de Goiânia - subsídio para um módulo de ensino relacionado à ciência-tecnologia-sociedade (CTS). In: GONÇALVES, O. D. (Org.). O ensino de física e a física da atualidade. Rio de Janeiro: Ed. UFRJ. (Trabalhos apresentados durante a $1^{\text {a }}$ Escola de Verão para Licenciados).

BARTHES, R. 1993. Mitologias. Rio de Janeiro: Bertrand Brasil.

BRASIL. Ministério da Educação e do Desporto. Secretaria de Educação Fundamental. Parâmetros Curriculares Nacionais: terceiro e quarto ciclos do ensino fundamental: ciências naturais. Brasília, 1998. 138p.

BRUNER, J. 1996. Toward a theory of Instruction. Cambridge: Harvard University Press. 
CAZELLI, S. 1992. Alfabetização Científica e os Museus Interativos de Ciências. Rio de Janeiro: Departamento de Educação da PUC-RJ. (Dissertação, Mestrado).

CHRÉTIEN, C. 1994. A Ciência em ação: mitos e limites. Campinas: Papirus. (Coleção Filosofia no Presente).

ENGUITA, M. F. 1988. Tecnologia e Sociedade: a ideologia da racionalidade técnica, a origem do trabalho e a educação. Educação e Realidade, Porto Alegre, vol. 13, n. 1, p.39-52, jan./jun. 1988.

FINNEGAN, R. 1988. Literacy and Orality: Studies in the Technology of Communication. Oxford: Basil Blackwell.

FORQUIN, J.C. 1993. Escola e Cultura. Porto Alegre: Artes Médicas.

FRANÇA, M. S. J. et al. O futuro é agora. Revista Época, São Paulo, n.33, p.36-103, jan. 1999.

GRUPO DE REELABORAÇÃo do ENSINO DE FíSICA - GREF. 1991. Física. São Paulo: USP. v. 1, 2 e 3.

HALLINGEN, H. 1998. Science \& Technology Studies. Wollongong: University of Wollongong.

LEVINE, D. 1995. Visões da Tradição Sociológica. Rio de Janeiro: Zahar.

LIGHTMAN, A. 1966. Sonhos de Einstein. São Paulo: Cia das Letras.

MCLUHAN, M., QUENTIN, F. 1967. The Medium is the Message. New York: Bantam.

MENEZES, L. 1988. Crise, Cosmos, Vida Humana: Física para uma Educação Humanista. São Paulo: Instituto de Física da USP. (Tese, Livre Docência).

MILLER, J. D. 1987. Science Literacy, in the United States. Communicating Science to the Public. In: EVERED, D., O’ CONNOR, M. (Eds.) London: Wiley.

MORAES, A. M. 1994. A inovação ciência, tecnologia e sociedade no ensino de ciências: uma análise sociológica. Revista de Educação, Lisboa, p.87-99.

MORIN, E. 1996. Ciência com Consciência. Rio de Janeiro: Bertrand Brasil.

MUSEU DE ASTRONOMIA E CIÊNCIAS AFINS - MAST. 1992. Quatro Cantos de Origem. São Paulo. (Projeto Museológico da Exposição Permanente). 
PIERSON, A. H. C., HOSOUME, Y. O cotidiano, o ensino de física e a formação da cidadania. In: ENCONTRO NACIONAL DE PESQUISA EM ENSINO DE CIÊNCIAS, 1, 1997, Águas de Lindóia - SP. Atas... Porto Alegre: Instituto de Física - UFRGS, 1997. p.86.

ROBEenS, K., Webster, F. 1989. The Technical Fix: Education, Computer and Industry. London: MacMillan.

RODRIGUES, A. M. 1997. Fundamentos em Filosofia da Tecnologia. Revista Tecnologia e Cultura, Rio de Janeiro, 1, n.1, p.11-8, jul/dez. 1997.

RUTHERFORD, F. J., AHLGREEN, A. 1995. Ciência para todos. Lisboa: Publicação Lid.

RYE, J. A. 1998. Teaching Beliefs and Practices of Research Scientist Faculty MemberEngaged in Science-Technology-Society (STS). Horgantown: West University.

SChARMANN, L. C. 1998. Preservice Secundary Science Teacher's Orientations Toward ScienceTechnology-Society (STS) Education. Manhattan: Kansas State University.

SHEN, B. S. P. 1975. Science Literacy. American Scientist, n. 39, p.265-68.

SOLOMON, J. 1993. Teaching Science, Technology and Society. Buckingham: Open University Press. (Coleção Developing Science and Technology Education).

ZANETIC, J. 1989. Física Também é Cultura. São Paulo: Faculdade de Educação da USP. (Tese, Doutorado).

ZIMAN, J. 1985. Enseñanza y Aprendizage sobre la Ciencia y la Sociedad. México: Fondo de Cultura Económica.

--------. 1978. Reliable Knowledge. An Exploration of the Grounds for Belief in Science. Cambridge: Cambridge University Press.

ZUCKERMAN, M. J. 1999. Computadores sofrem outras ameaças. Folha de São Paulo, São Paulo, 06 jun. 1999. Informática, 5, p.3. 
Abstract: The article shows that it is possible and necessary to develop scientific literacy by integrating formal with non-formal education. It is argued that the idea of scientific literacy is directly linked to the Science, Technology and Society approach to science education. The meanings of scientific literacy and CTS are reviewed and the importance of including narrative, myth, science and technology in science education defended. It is also reported the results of a survey conducted with different members of the public of Museu de Astronomia e Ciências Afins in Rio de Janeiro (108 teachers attending a course, 18 participants a seminar plus groups of visiting students). The survey shows, on the one hand, the possibilities seen by teachers on choosing to teach science through a CTS perspective. On the other hand, it shows the incoherence that emerges when certain academic topics are explored when students visit a science museum.

\section{Correspondência:}

Maria Cristina Leal; Avenida Borges de Medeiros 3371/401 -Rio de Janeiro, RJ - cep 22.470001. Correio eletrônico: leal4512@rionet.com.br.

Guaracira Gouvêa de Sousa; Rua Belizário Távora 431/401 - Rio de Janeiro, RJ - cep 22.245070.

Submetido em 15/01/1998, aceito para publicação em 23/11/1999. 